\title{
The Various Implications of English Phonics Learning Among Chinese School-age Children
}

\author{
Huanhuan $\operatorname{Ren}^{1, \mathrm{a}^{*}}$ and Chi Ma ${ }^{2, \mathrm{~b}}$ \\ ${ }^{1}$ Teaching and Research Institute of Foreign Languages, Bohai University, Jinzhou 121013, China \\ 2 Jinzhou Institute of Forestry Research, Jinzhou Forestry Bureau, Jinzhou 121013, China \\ arenhuanhuan2014@163.com, ${ }^{b}$ machi2014@tom.com
}

\section{Keywords: English Phonics; Implications; Chinese School-age Children}

\begin{abstract}
It's much more important for children in non-English speaking countries to get to know phonics than grammars for further success in English learning. However, it's argued that the shortcomings of English phonics learning among Chinese school-age children can be reflected in three areas of phonics learning, namely, no much vocabulary in listening and speaking, no much listening practice for phonemic awareness, and no much reading for active vocabulary. The implications of English phonics learning among Chinese school-age children are supposed to rest on carrying out three tasks in phonic learning, that is, an essential make-up for sight words, an intensive training for auditory processing, and a love of reading for pleasure. It's hoped that this research provides a useful reference for future phonics instruction and learning practice among young English language students in China.
\end{abstract}

\section{Introduction}

Phonics has proven time and again to be the most effective way to get children reading early[1]. Since phonics knowledge and skills are critical to becoming literate, are young children from non-English speaking countries supposed to learn English phonics as well? If young children from non-English speaking countries, such as Chinese school-age children, spend more attention on learning phonics, could they get the same skills that native learners may easily obtain? What kinds of disadvantages or shortcomings may Chinese school-age children be faced with in the process of learning phonics? What efforts can phonics teachers or parents in non-English speaking countries make to help them out and make full use of English phonics opportunities? In this thesis, we attempt to argue for the threads and trends of phonics instruction, get insights into the shortcomings of English phonics learning among Chinese school-age children, and reach for the various implications of English phonics learning among Chinese school-age children. This paper is a summary of this research work, which hopefully provides a useful reference for future phonics instruction and learning practice among young language students in China.

\section{The Threads and Trends of Phonics Instruction}

The Rise of Phonics. What is phonics? Why is phonics popular? Phonics is the ability to identify that there is a relationship between the individual sounds (phonemes) of the spoken language and the letters (graphemes) of the written language[2]. Before children learn to read print, they need to become more aware of how the sounds in words work. Compared with the IPA (International Phonetic Alphabet) symbols, phonics seems to have much more advantages, such as decoding abilities and encoding skills developed on learners[3]. It's made obvious that learning to blend and segment words through phonics is a critical foundation for becoming successful readers and spellers. Moreover, IPA, in practice, can be related to phonics through helping crystallize some confusing word pronunciation and remind learners to read words more accurately[4]. Phonics instruction ranges from teaching letter identification, letter-sound relationships, spelling patterns, high frequency words, complicated vowel patterns, to multisyllabic words. Overall, there are three different methods for teaching phonics: synthetic phonics, analytic phonics and analogy phonics, with each method of phonics is drawn by instructors on at 
different points in teaching[5]. Though many researchers are favor of synthetic phonics instruction, the matter of which method to be adopted is still depending on the instructional purpose and context in English language learning[6].

Development of Phonics. Phonics teaching could trace back to the reform of the Catholic Church at a time when English was not prohibited in the church and was used to translate Bible to make all the English believers understand God[7]. Meanwhile, an easy and singular way of learning English, named phonics, was invented to teach English[8]. In 1790s, phonics was widely applied in American reading instruction. However, with the fad of the whole-word method from the late 1930s to 1940s, phonics was at the center of controversy[9]. In 1955, Rudolf Flesch firmly advocated a return concern to phonics. In North America, phonics method as a new model of second language teaching has become the prevailing teaching method since the 1990s[10]. Nowadays, it's suggested that phonics should be heavily emphasized in early grades so as to develop a solid foundation for more advanced decoding skills[11]. It is also hold that it's often best to start learning to read through phonics from preschool to 2 nd grade or from about ages 3 to 8[12]. And Karen stresses that phonics should be a strong component of all kindergarten and $1 \mathrm{st}$ grade instruction, so that students build strong word attack skills as a foundation for all of their reading skills. Instruction should consist of a planned sequence of instruction taught in a systematic way[13]. However, it's found that phonics instruction is not a panacea for teaching all students and older readers may well have other issues beyond decoding that interfere with efficient reading so simply providing training in phonics may not solve a struggling reader's problems[14].

Phonics Instruction in China. Phonics instruction is largely embraced by EFL learners in Asian countries such as China, based on the promise that phonics is an effective teaching instruction not only for young native speakers but also for EFL learners[15]. However Susan Verner argues that phonics is sometimes a controversial subject among ESL teachers, since traditional classrooms are pushing for sight words and deemphasizing or totally eliminating phonics[16]. Thus how beneficial is it to learn phonics for EFL learners? Lizzy discussed in her paper that phonics instruction can help EFL students to improve their listening and speaking skills, together with their pronunciation and intonation[17]. Susan proposes that benefits of learning phonics for ESL learners are alphabet, spelling, unknown words, word roots and confidence, while the drawbacks are reading without understanding, no help with familiar words' recognition, too many exceptions, and too much extra effort[18]. It's recommended that EFL younger learners are shown the ability to learn a foreign language in many researches and thereby phonics should be taught systematically as part of a balanced and integrated English language program[19]. Emphasizing the oral aspect of language - speaking, listening, phonology - will help students of phonics develop a more well-rounded and more effective English learning strategy[20].

\section{The Shortcomings of English Phonics Learning among Chinese School-age Children}

No much Vocabulary in Listening and Speaking. Native speaks are exposed to authentic English language when they are born, and their life is replete of different English sounds from parents, friends and teachers, etc. Do Chinese children experience this formidable English learning advantages? Definitely not. Chinese people are born in an environment rich in Chinese speech sounds other than English speech sounds. It's hard to imagine how significant the process of English phonics learning may be for people without a big store of English speech sounds. Would Chinese children know the common words used in daily life like igloo, when they are taught the speech sound /i/. There is no connection between the meaning of the word of igloo with the form and sound of it if learners have no idea about the sound /iglu/ even if they are able to sound out by themselves with the help of the knowledge of phonics. For example, in serial books of Jolly Phonics, learners are taught to recognize the first six sounds, $s, a, t, i, p, n$, as they can form more simple three-letter words than any other six letters, namely sat, pin, tip, tap, ant, pat, tin, to name just a few[21]. Even if learners have the ability to blend sounds, namely running the sounds together to make words, how much sense can it make if learners are not informed of the meaning of those words? Can phonics go any further in their English language learning? 
In this respect, a certain amount of words especially sight words in listening and speaking is very important for any phonic learner who wants to benefit from it.

No Much Listening Practice for Phonemic Awareness. Although children have different learning styles, Chinese school-age children seem to be trained to be visual learners who just learn English language by seeing rather than by listening as auditory learners do. It's made evident that English learners in China are slated to be deaf and dumb in the scenario of multicultural communication due to the inability to understand others and express themselves. As we know that all English words are made up of sounds. The sounds of English words are expected to be part of learning for English language learners. In order to excel in English written tests, few Chinese school-age children would like to spare no efforts in spending time listening to English materials, such as stories, fictions, news, and dialogues. Whether in the classroom, for home schooling, or other educational situations, listening practice is never the first choice made by Chinese school-age children in learning English language, not alone the learning of phonemes and the cultivation of phonetic awareness. It's found that phonics and phonemic awareness are closely related, and learning about one aspect reinforces the other[22]. Both of them are concerned with sounds, with phonemic awareness involving spoken language and phonics involving written language[23]. The lack of phoneme listening and phonemic awareness practice may lead to frustration in future English learning, especially in the aspect of English listening and speaking.

Not Much Reading for Active Vocabulary. Phonics is regarded as the fastest way to learn to read. How does it work? Children who cannot hear and work with the phonemes of spoken words will have difficulties learning how to relate these phonemes to graphemes when they see them in written words[24]. In other words, a student's skill in phonemic awareness is a good predictor of later reading success or difficulty. If he or she can possess phonemic skills in recognizing which words in a set of words start with the same sounds, blending the separate sounds in a word and segmenting a word into its separate sounds, the kid is more likely to be successful in reading and comprehension of English language as an early reader. Native speakers do well in this part because they are more familiar with and be skillful in dealing with word sounds rather than word forms. If English learners have a poor memory for symbols and words, it's not easy for children to learn the blend sounds in reading. EFL learners not possessing a wealthy store of phonemes in different words are just stuck into this tricky situation, even if they try very hard through systematic phonics. So phonics working for native speakers doesn't necessarily mean that it will definitely have fundamental effects on cultivating reading abilities of Chinese school-age learners. But reading still makes sense for Chinese school-age children because it's still believed that they may gain a large vocabulary in contexts with multiple word exposures in reading. Meanwhile, Chinese school-age children could gain some insights into English literature or culture through phonics learning.

\section{The Implications of English Phonics Learning among Chinese School-age Children}

An Essential Make-up for Sight Words. For young learners who struggled with phonics at the very beginning, recognition of sight words is good recipe for it. Sight words are those words that a reader must learn to recognize immediately by sight, instead of by sounding them out, because these sight words do not follow regular spelling rules and can not be sounded out. Hence the name, sight words. Sight words occur with high frequency in easy texts. It's found that every time the child reads a text, 50-75 percent of the words he or she encounters are from the Dolch sight word list, a core group of 220 common words that are represented frequently in reading material[25]. After learners have boosted their decoding and comprehension skills and are enabled to piece together all the words and letters they decode, learners are ready for a stronger reading fluency with the help of sight words. It's crucial to familiarize young learners with the sight words they will most frequently encounter in texts, as learning to recognize these words at sight is a critical skill for fluent reading. Children need extra practice to learn these words, because many of which can't be represented by simple pictures. Instead of forcing rote memory of whole words through flash card drill, they are believed to learn phonics and sight words better when they are taught either in context or via fun and memorable activities that access a variety of 
learning styles and modalities. These aspects of literacy can be challenging to teach and learn. In light of the fact that children ages five through eight will find memorizing these words both simple and fun, Chinese school-age children should be involved into sight words learning especially in the speech sounds of those words as early as possible.

An Intensive Training for Auditory Processing. For EFL learners who strive to be excel in English learning should never miss the chances of listening to English language. A lot of learning platforms are set up so that learners can easily find out listening material by type and level. Resources can cover everything from nursery rhymes, folk songs, audio books, TV talks to news reports, ranging from antenatal listening material, preschool listening material, kindergarten listening material to school listening material. It's a great way of learning English when starting from being able to clearly hear and distinguish phonemes through listening. With an intensive training for auditory processing, the child will have the confidence to identify the vowels, consonants and syllables and can at least attempt to read the word in an accurate and precise way. This ability to hear and manipulate individual phonemes, which is called phonemic awareness, has a significant, positive and robust impact on students' learning outcomes, and is quite easy to be cultivated among young children. Despite the fact that some scholars believe there is no single magic age for EFL learning, or say second-language learning is not necessarily subject to biological critical periods, it's proved that, on average, there is a continuous decline in ability to learn with age[26]. Moreover, it's further found that, attention, short-term memory and long-term memory are developing between the ages of 2 and 5; Auditory processing, which is critical for good reading skills is developing between the ages of 5 and 7; Logic and reasoning also becomes more established during after five years of age as a child becomes better able to make connections between ideas[27]. Therefore, learners should develop sound sense and sharpen pronunciation through auditory learning at the very early time.

A Love of Reading for Pleasure. Learning the rudiments of phonics may be easy but it's by no means enough. People learn phonics is for the sake of using the letter sounds to read and write words. That's why phonics is regarded as a method for teaching reading and writing of the English language by developing learners' phonemic awareness in order to teach the correspondence between these sounds and the spelling patterns that represent them[28]. Considering a vast amount of phonemes in mind and a sound phonemic awareness formed unconsciously by native learners, phonics learning to native speakers is just a way of connecting the word sounds heard in daily life with word forms strange to them, in hope that they can ultimately go for further autonomous reading with increased vocabulary. In order to give Chinese school-age children the early literacy skills they need to become successful readers, fundamental reading skills, like phonics, phonemic awareness and fluency, are supposed to be taught before real reading. A lot of storybooks can be studied to provide this progressions. It is easier if reading begins with storybooks providing simple words that are suitable for blending practice. Ability can be developed by asking a child question about a story they have just read. These are all great ways to really help young learners to succeed in literacy development. And keep in mind that every child learns differently and reading material can be easily differentiated to meet students' needs. Once there is fluency in reading, the most important skills for a child will be comprehension and the understanding of more words. Thus, learners especially EFL learners can prepare themselves the way for a lifetime of reading for pleasure.

\section{Conclusion}

Teaching English phonics is critical for literacy development of native young learners. However, it's argued that the shortcomings of English phonics learning among Chinese school-age children can be reflected in three areas of phonics learning, namely no much vocabulary in listening and speaking, no much listening practice for phonemic awareness, and no much reading for active vocabulary.The implications of English phonics learning among Chinese school-age children are supposed to rest on carrying out three tasks in phonic learning, that is, an essential make-up for sight words, an intensive training for auditory processing, and a love of reading for pleasure. It's hoped that this research provides a useful reference for future phonics instruction and learning practice among young English language 
students in China.

\section{Acknowledgements}

This work is part of the project of On Intrinsic Logics, Main Implications and Intervetnion Reserach of English Phonics Enlightenment among Chinese School-age Children. This research was supported by the fund of Liaoning Planning of Philosophy and Social Science (Project No. L17CYY005).

\section{References}

[1][12]About Learning to Read with Phonics. Information on https://www.kizphonics.com/what-is-phonics/

[2][11][13][14] K. Tankersley. The Threads of Reading: Strategies for Literacy Development. ASCD, 2003.

[3][4][15][19] H.H. Ren, C. Ma. The impact of Phonics instruction on pre-school learners' development in English language course. In J. Wang, N. Xin and H. Y. Zhou (eds.). Advances in Computer Science Research v 59. Paris: Atlantis Press. December 2016, pp.674-679.

[5][6][7] H.H. Ren, C. Ma. Study on the practice of phonics in English vocabulary teaching for primary school students. In J. Wang, N. Xin and H. Y. Zhou (eds.). Advances in Computer Science Research v 59. Paris: Atlantis Press. December 2016, pp.1095-1099.

[8] [9][10]Z. Yu. An Application Study of Phonics in English Phonology and Vocabulary Teaching in Primary School, Jiangxi Normal University, 2011.

[16][18][20] S. Verner. Phonics in the ESL Classroom - Is it right for you? Information on https://busyteacher.org/16913-teach-phonics-esl-classroom.html

[17] Lizzy, The research on phonics instruction of English words teaching in the primary school, Chongqing Normal University, 2006.

[21] Jolly Phonics Parent/Teacher Guide. Jolly Learning Ltd.

[22][23] NSW Department of Education and Training. Literacy Teaching Guide: Phonics, 2009.

[24]What is Phonemic Awareness? Information on http://www.begintoread.com/articles/phonemic-awareness.html

[25] S. Keeley, R. Simard, C. Schneider, M. Stephens, J, Trasler. The complete book of sight words: 220 words your child needs to know to become a successful reader. Flash Kids, 2011.

[26] E. Bialystok, K. Hakuta. In other words: The science and psychology of second language acquisition, New York: Basic Books, 1994.

[27]Cognitive Stages for Child Development. Information on http://www.learningrx.com/cognitive-stages-for-child-development.htm

[28] Phonics. Information on https://en.wikipedia.org/wiki/Phonics 